\title{
Correlation of hypoxia inducible factor-1 $\alpha$ and vascular endothelium growth factor in rat myocardium during aerobic and anaerobic exercise
}

\author{
Rostika Flora, ${ }^{1}$ Hans-Joachim Freisleben, ${ }^{2}$ Frans Ferdinal, ${ }^{3}$ Septelia I. Wanandi, ${ }^{2,4}$ Mohamad Sadikin ${ }^{2,4}$ \\ ${ }^{1}$ Faculty of Medicine, Universitas Srivijaya, Palembang, Indonesia \\ ${ }^{2}$ Study Program Biomedical Sciences, Faculty of Medicine, Universitas Indonesia, Jakarta, Indonesia \\ ${ }^{3}$ Faculty of Medicine, Universitas Tarumanegara, Jakarta, Indonesia \\ ${ }^{4}$ Department of Biochemistry and Molecular Biology, Faculty of Medicine, Universitas Indonesia, Jakarta, Indonesia
}

\begin{abstract}
Abstrak
Latar belakang: Aktivitas fisik mengakibatkan peningkatan kebutuhan oksigen. Oksigen diperlukan untuk fosforilasi oksidatif dalam rangka menghasilkan ATP. Tingginya kebutuhan oksigen selama aktivitas fisik yang tidak diikuti dengan kemampuan suplai oksigen yang cukup, mengakibatkan terjadi hipoksia di jaringan otot. Dalam kondisi hipoksia gen utama yang mengalami upregulasi adalah Hypoxia Inducible Factor-1 $\alpha$ (HIF-1 $\alpha)$. Melalui aktivitas HIF-1 $\alpha$, ekspresi sejumlah gen akan mengalami peningkatan guna mengurangi ketergantungan sel terhadap oksigen sekaligus meningkatkan pasokan oksigen ke jaringan, termasuk gen VEGF. Pada otot jantung belum diketahui apakah aktivitas fisik juga mengakibatkan hipoksia serta apakah HIF-1 $\alpha$ dan VEGF berperan dalam mekanisme adaptasi. Penelitian ini bertujuan untuk melihat korelasi antara HIF-1 $\alpha$ dan VEGF dalam jaringan otot jantung tikus yang diberi aktivitas fisik aerobik dan anaerobik.
\end{abstract}

Metode: Jaringan otot jantung berasal dari tikus yang diberi aktivitas fisik aerobik dan anaerobik menggunakan treadmill selama 1, 3, 7 dan 10 hari. Kemudian dilakukan pengukuran konsentrasi HIF-1 $\alpha$ dan konsentrasi VEGF jaringan.

Hasil: Hasil penelitian menunjukkan terjadinya peningkatan protein HIF-1 $\alpha$ dan VEGF $(p<0,05)$ pada kelompok yang diberi perlakuan aktivitas fisik aerobik dan anaerobik. Peningkatan konsentrasi HIF-1 $\alpha$ tertinggi terjadi pada hari pertama perlakuan dan konsentrasi HIF-1 $\alpha$ kelompok anaerobik lebih tinggi dibandingkan kelompok aerobik (156,8 $\pm 33,1$ vs $116,03 \pm 5,66)$. Begitu pula dengan konsentrasi VEGF pada kelompok anaerobik konsentrasi tertinggi terjadi pada hari pertama (36,37 $\pm 2,35)$, sedangkan pada kelompok aerobik konsentrasi VEGF tertinggi terjadi pada hari ke-3 (40,66 \pm 1,73). Terdapat korelasi antara konsentrasi HIF-1 $\alpha$ dan konsentrasi VEGF jaringan dengan tingkat korelasi sedang $(r=$ 0,59) pada kelompok aerobik dan korelasi yang kuat pada kelompok anaerobik $(r=0,69)$.

Kesimpulan: Aktivitas fisik aerobik dan anaerobik mengakibatkan peningkatan konsentrasi HIF-1 $\alpha$ dan VEGF pada otot jantung tikus dalam pola yang spesifik. Kondisi anaerobik memicu peningkatan kebutuhan vaskularisasi lebih kuat dan lebih dini dibandingkan kelompok aerobik. (Med J Indones. 2012;21:133-40)

\begin{abstract}
Background: Exercise increases the need for oxygen to generate ATP through oxidative phosphorylation. If the high energy demand during exercise is not balanced by sufficient oxygen supply, hypoxia occurs in skeletal muscle tissue leading to upregulation of hypoxia inducible factor- $1 \alpha(\mathrm{HIF}-1 \alpha)$. The activity of HIF-1 $\alpha$ increases the expression of various genes in order to reduce the metabolic dependence on oxygen and to increase oxygen supply to the tissue, e.g., VEGF which plays a role in angiogenesis. In myocardium, it is unlcear whether exercise leads to hypoxia and whether HIF-1 $\alpha$ and VEGF play a role in the mechanism of hypoxic adaptation. This study aimed to investigate the correlation of HIF-1 $\alpha$ and VEGF in heart muscle tissue of rats during aerobic and anaerobic exercise.
\end{abstract}

Methods: A rat treadmill was used with a specific exercise program for 1, 3, 7 and 10 days. The concentrations of HIF-1 $\alpha$ and VEGF were measured the myocardium.

Results: Both, HIF-1 $\alpha$ protein and VEGF were increased $(p<0.05)$ in the groups with aerobic and anaerobic exercise. Concentrations of HIF-1 $\alpha$ were highest on the first day of activity, being higher in the anaerobic than in the aerobic group $(156.8 \pm 33.1$ vs. $116.03 \pm 5.66)$. Likewise, the highest concentration of VEGF in the group with anaerobic exercise occurred on the first day $(36.37 \pm 2: 35)$, while in the aerobic group, VEGF concentration was highest on day 3 (40.66 \pm 1.73$)$. The correlation between the myocardial tissue consentrations of HIF- $1 \alpha$ and VEGF is moderate $(r=0.59)$ in the aerobic group and strong in the anaerobic group $(\mathrm{r}=0.69)$.

Conclusion: Aerobic and anaerobic exercise increase HIF-1 $\alpha$ and VEGF concentrations in rat myocardium in specific patterns. The anaerobic condition triggers vascularization stronger and obviously earlier than aerobic exercise. (Med J Indones. 2012;21:133-40)

Keywords: Exercise, HIF-1 $\alpha$, myocardium, VEGF

Exercise is regular physical activity within a certain period of time and intensity, which aims to increase physical performance and to keep the body healthy and fit. In addition to maintaining physical fitness, physical exercise is recommended for preventive, curative and rehabilitative programs in an effort to improve health, especially of the heart. Considering energy metabolism, there are two forms of exercise, aerobic and anaerobic. Aerobic condition produces a minimum of $30 \mathrm{~mol}$ ATP by mitochondrial oxidative phosphorylation with 
glucose from glycogen and free fatty acids as the main metabolic sources of energy. The process depends on the availability of molecular oxygen. Anaerobic exercise does not use oxygen in the metabolic process of energy conservation. In the latter case, formation of ATP uses free glucose via glycolysis yielding only 2 mol per mol glucose or creatine phosphate via phosphocreatine kinase. ${ }^{1}$

Exercise leads to increased oxygen demand, which is required in oxidative phosphorylation forATP production. The latter provides the energy to perform muscle contraction during exercise. ${ }^{2}$ Unbalanced metabolism under high oxygen demand and insufficient supply of oxygen results in hypoxia in skeletal muscle tissue. ${ }^{3}$ Hypoxia triggers the metabolic adaptation responses at systemic physiological and molecular levels. ${ }^{4}$

Exercise triggers the expression of genes involved in the corresponding metabolic condition. This expression is influenced by external and internal factors such as changes in oxygen concentration or cellular pathways. Hypoxia inducible factor-1 (HIF-1), a heterodimer composed of subunits HIF- $1 \alpha$ and HIF$1 \beta$ exerts increased activity (up-regulation) in hypoxic conditions. Both subunits are constitutively transcribed and translated. In normoxic condition, HIF- $1 \alpha$ degrades rapidly, but is stable in hypoxia. Consequently, HIF-1 plays a role in maintaining energy metabolism and oxygen balance. ${ }^{5}$ It regulates the expression of various genes with a wide range (so-called master regulatory gene) including genes involved in erythropoiesis, glucose metabolism and angiogenesis.

Angiogenesis is the formation of new capillary vessels as muscle adaptation in response to decreased oxygen levels. Angioneogenesis occurs due to an imbalance between the metabolic needs of the tissue and the capacity of vascular blood perfusion. An important regulator of angiogenesis is the vascular endothelial growth factor (VEGF). Hypoxia increases VEGF expression through regulation via HIF-1. In skeletal muscle, increased HIF- $1 \alpha$ and HIF-1 $\beta$ levels are associated with an increase in VEGF mRNA, i.e., HIF-1 activation affects VEGF gene expression. ${ }^{6}$

Although HIF-1 is known as a regulator of VEGF mRNA, its role in molecular adaptation to exercise in the myocardium is still unclear. Previous studies rather discussed molecular mechanisms of hypoxia caused by pathologic conditions of the heart muscle in relation to exercise, ${ }^{7}$ whereas molecular research in the field of sports health focused on the influence of hypoxia on skeletal muscle. In normal myocardium, it is not known whether aerobic and anaerobic exercise results in hypoxia as in skeletal muscle. If exercise leads to hypoxia in the heart, it must be clarified whether HIF- $1 \alpha$ plays a role in the adaptation via the same mechanisms as in skeletal muscle. In addition, it should be investigated whether HIF-1 $\alpha$ correlates with VEGF expression in order to adapt to hypoxic condition in heart muscle during exercise.

\section{METHODS}

This experimental animal study was conducted in the animal house of the Faculty of Medicine Universitas Indonesia between August 2009 and August 2010. Forty-five male Wistar rats, 6 - 8 weeks old weighing 80-100 g were assigned randomly to a control group (P1) and eight exercise groups (P2-P9). Some rats died during exercise, some rats were lazy, not running properly and not following the exercise protocol on the treadmill. At the end, each group provided data of three rats $(\mathrm{n}=3)$, which was calculated as the animal requirement of our study. Four groups performed aerobic (P2-P5) and four anaerobic (P6-P9) exercise. For aerobic exercise a treadmill at a speed of $20 \mathrm{~m} / \mathrm{min}$ was used continuously for 30 minutes and for the groups performing anaerobic exercise the speed was adjusted to $35 \mathrm{~m} / \mathrm{min}$ continuously for 20 minutes. Execise on the treadmill was performed for 1, 3, 7 and 10 days. The experimental procedure for aerobic and anaerobic exercise was adapted from the method of Fahrenia, $2010,{ }^{8}$ which in turn is based on the method of Soya et al. ${ }^{9}$ All rats were acclimated to the treadmill for 1 week by exposing them to the apparatus moving at low speed.

The determination of biomedical parameters (e.g., HIF$1 \alpha$, VEGF) was accomplished in the laboratory of the Department of Biochemistry and Molecular Biology, Faculty of Medicine, Universitas Indonesia. To confirm the influence of the exercise on oxygen supply in the body, routine blood gas analysis was carried out with heparinized aortic blood using a Corning 165 Blood Gas Analyzer. The values of oxygen partial pressure $\left(\mathrm{P}_{\mathrm{O} 2}\right)$, oxygen saturation $\left(\mathrm{Sat}_{2} \mathrm{O}_{2}\right), \mathrm{P}_{\mathrm{CO} 2}$ and $\mathrm{pH}$ are presented in Table 1. Further hematological data were obtained from a Sysmex KX21 Hematology Analyzer using venous EDTA-blood (data not shown).

The study was approved by the Ethical Committee of the Faculty of Medicine Universitas Indonesia. At the end of the experimental period, the rats were decapitated and the hearts excised. Cardiac muscle tissue was stored at $-70^{\circ} \mathrm{C}$ until processed.

\section{Measurement of HIF-1a}

At the days indicated, cardiac muscle tissue was weighed and homogenates prepared by adding lysis 
buffer. HIF-1 $\alpha$ concentrations were measured by sandwich ELISA using Surveyor TM IC Human / Mouse Total HIF-1 $\alpha$ Immunoassay kits (Cat. SUV 1935, R \& D Systems).

\section{Measurement of VEGF}

Measurement of VEGF concentration in heart muscle tissue was carried out with Quantikine Mouse VEGF kit (Cat. MMV00, R \& D Systems).

\section{Statistics}

The research data were processed using SPSS 17.0 software. ANOVA was conducted to examine mean differences between the groups with significance level of $p<0.05$. To determine correlation between HIF- $1 \alpha$ and VEGF, Pearson test was used.

\section{RESULTS}

\section{Blood gas analysis}

Oxygen partial pressure $\mathrm{P}_{\mathrm{O} 2}$ as a measure of oxygen supply was reduced in all exercise groups vs. controls, highly significant in the average of anaerobic groups and not significant $(p=0.149)$ in the average of aerobic groups (Table 1$)$. The latter value $(66.5 \mathrm{mmHg})$ was almost twofold higher than in the anaerobic groups $(34.04 \mathrm{mmHg}$ ). Oxygen saturation was also significantly reduced versus controls, highly significant $(p=0.009)$ in anaerobic and significant $(p=0.017)$ in aerobic exercise.

Carbondioxide partial pressure $\left(\mathrm{P}_{\mathrm{CO} 2}\right)$ was increased in all anaerobic and aerobic groups. The anaerobic average $(59.93 \mathrm{mmHg})$ was higher than the aerobic value $(56.86 \mathrm{mmHg})$; however, the latter differed with high significance $(p=0.005)$ from controls $(37.93$ $\mathrm{mmHg}$ ) because of its low standard deviation (SD) of \pm 4.92 , whereas the high SD of \pm 12.92 in the anaerobic average made it not significant $(\mathrm{p}=0.088)$. The $\mathrm{pH}$ values were lower in all exercise groups than in controls $(\mathrm{pH} 7.07)$ and slightly lower in the anaerobic $(\mathrm{pH} 6.92)$ than in the aerobic average ( $\mathrm{pH}$ 6.98). All differences in $\mathrm{pH}$ values between the groups were not statistically significant (Table 1).

\section{The concentration of HIF-1a}

On the first day, the concentrations of HIF-1 $\alpha$ in heart muscle increased significantly both in aerobic and anaerobic exercise compared to the control group (Figure 1). In the aerobic group, HIF- $1 \alpha$ concentration increased to $254 \%$ of controls, whereas it was $343 \%$ in the anaerobic group. Then, the concentrations decreased again to reach about control values on days 7 and 10. On day 3, HIF$1 \alpha$ concentration in the aerobic group was still $210 \%$ of controls, whereas in the anaerobic group it reached almost the control value $(121 \%)$. This difference between the two exercise groups was statistically significant $(\mathrm{p}<0.05)$.

Table 1. Blood gas analysis: partial oxygen pressure, oxygen saturation, partial carbondioxide pressure and $\mathrm{pH}$ under aaerobic and anaerobic conditions

\begin{tabular}{lcccccccc}
\hline Parameter & \multicolumn{2}{c}{$\mathrm{P}_{\mathrm{O} 2}[\mathrm{mmHg}]$} & \multicolumn{2}{c}{$\mathrm{Sat}_{2}[\%]$} & \multicolumn{2}{c}{$\mathrm{P}_{\mathrm{CO} 2}[\mathrm{mmHg}]$} & \multicolumn{2}{c}{$\mathrm{pH}$} \\
\hline Condition & anaerobic & aerobic & anaerobic & aerobic & anaerobic & aerobic & anaerobic & aerobic \\
\hline Control & $90.23 \pm 1.357$ & \multicolumn{2}{c}{$91.40 \pm 2.046$} & \multicolumn{2}{c}{$37.93 \pm 3.724$} & $7.07 \pm 0.048$ \\
Day 1 & 35.83 & 36.78 & 39.45 & 34.28 & 44.13 & 52.88 & 6.86 & 6.94 \\
& \pm 14.03 & \pm 1.50 & \pm 16.14 & \pm 4.83 & \pm 4.92 & \pm 15.53 & \pm 0.101 & \pm 0.029 \\
Day 3 & 50.77 & 76.60 & 71.77 & 40.53 & 50.30 & 52.07 & 6.97 & 6.94 \\
& \pm 1.03 & \pm 2.04 & \pm 10.19 & \pm 19.04 & \pm 7.48 & \pm 3.37 & \pm 0.054 & \pm 0.033 \\
Day 7 & 20.77 & 84.67 & 32.57 & 68.63 & 71.63 & 58.13 & 7.02 & 7.05 \\
& \pm 6.32 & \pm 4.26 & \pm 3.84 & \pm 0.45 & \pm 10.79 & \pm 2.33 & \pm 0.059 & \pm 0.019 \\
Day 10 & 28.78 & 67.93 & 25.45 & 66.73 & 73.66 & 64.37 & 6.81 & 6.98 \\
& \pm 8.30 & \pm 32.56 & \pm 3.10 & \pm 3.31 & \pm 21.11 & \pm 8.47 & \pm 0.173 & \pm 0.014 \\
Average & 34.04 & 66.50 & 42.40 & 52.54 & 59.93 & 56.86 & 6.92 & 6.98 \\
& \pm 11.03 & \pm 18.15 & \pm 17.71 & \pm 15.31 & \pm 12.92 & \pm 4.92 & \pm 0.084 & \pm 0.045 \\
Significance & high s. & n.s. & high s. & signific & n.s. & high s. & n.s. & n.s. \\
p vs C & 0.000 & 0.149 & 0.009 & 0.017 & 0.088 & 0.005 & 0.105 & 0.137 \\
anaer vs aer & $\mathrm{p}=0.066$ & $\mathrm{p}=0.333$ & $\mathrm{p}=0.412$ & p $=0.265$ \\
\hline
\end{tabular}

Blood gas analysis was routinely conducted $\left(\mathrm{n}=3\right.$ in each group), $\mathrm{P}_{\mathrm{O} 2}=$ partial oxygen pressure, Sat $\mathrm{O}_{2}=$ oxygen saturation, $\mathrm{P}_{\mathrm{CO} 2}=$ partial carbondioxide pressure, $\mathrm{C}=$ control, signific $=$ significant, $\mathrm{n} . \mathrm{s} .=$ not significant, high $\mathrm{s} .=$ high significance, anaer vs aer $=$ anaerobic versus aerobic conditions 


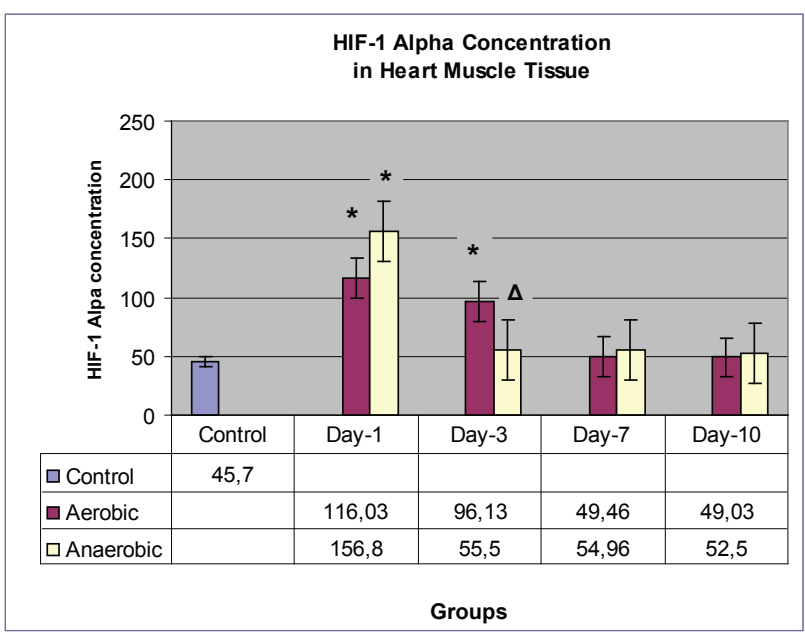

Figure 1. The concentration of HIF-1 $\alpha$ in myocardium; *significant difference compared with control group $(p<0.05)$

${ }^{4}$ significant difference between aerobic and anaerobic groups $(p<0.05)$

\section{The concentration of VEGF}

The concentration of VEGF in myocardium (Figure 2) was significantly increased in all aerobic groups compared with the control group. Likewise, in the anaerobic groups, significant difference occurred towards the control group except for day 10. In the aerobic groups, VEGF concentration was highest on the first day $(373 \%)$, then decreased ( $344 \%$ on day 3$)$ to $263 \%$ on day 7 and $143 \%$ on day 10 . In the aerobic group, VEGF concentration was $291 \%$ of controls on the first day and increased further to $417 \%$ on day 3 . Then VEGF concentration decreased to $305 \%$ on day 7 and to $209 \%$ on day 10 . Differences between the groups of aerobic and anaerobic activities were significant on the $1^{\text {st }}, 3^{\text {rd }}$ and $10^{\text {th }}$ days.

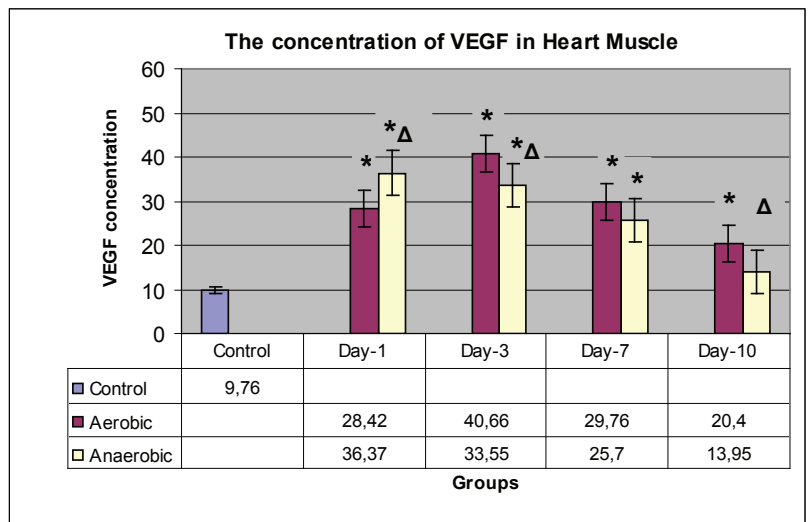

Figure 2. The concentration of VEGF in myocardium;

*significant difference compared with control group $(p<0.05)$;

$\Delta$ significant difference between aerobic and anaerobic groups $(p<0.05)$

\section{Correlation between HIF-1 $\alpha$ and VEGF}

The regression correlation between HIF- $1 \alpha$ and VEGF in the aerobic groups is moderate $(\mathrm{r}=0.59)$ and strong in the anaerobic groups $(r=0.69)$ (Figure. 3 and 4$)$.

\section{DISCUSSION}

The treadmill exercise model applied in our study leads to a rapid decrease in partial oxygen pressure on the first day of exercise, both in anaerobic and aerobic condition. Whereas aerobic exercise quickly recovers in the course of the experiments, $\mathrm{P}_{\mathrm{O} 2}$ stays low in anaerobic condition (Table 1). This indicates well that we used a valid exercise model differentiating between aerobic and anaerobic conditions. The other parameters of hypoxic or normoxic condition shown in Table 1 exert similar trends, although not as clear as partial oxygen pressure, oxygen saturation fluctuates but follows the same pattern. Partial carbondioxide pressure shows the opposite trend, it increases under exercise, more in anaerobic than in aerobic condition. Decrease of $\mathrm{pH}$ is the fourth indicator of hypoxic conditon under exercise measured in our study, its decrease is slightly more expressed in anaerobic than in aerobic condition.

Statistical significance should not be overestimated in this context, first the model is not absolute, fully anaerobic on one hand and fully aerobic on the other. Second, the numbers of our experimental animals and thus of our samples were low $(n=3)$ for blood gas measurements and third, individual fluctuations in some groups were considerable. However, these shortcomings do not alter the total picture of a valid model for anaerobic and aerobic exercise. ${ }^{8,9}$

In accordance with blood gas analysis, HIF-1 $\alpha$ concentration increased significantly in the myocardium on the first day of aerobic and anaerobic exercise compared to the control group (Figure 1) indicating hypoxia. The state of hypoxia affects several genes that play a role in the regulation of oxygen homeostasis, such as erythropoietin (EPO) and VEGF. Their transcription is controlled by HIF-1. Hypoxia inhibits the activity of prolyl hydroxylase domain-containing (PHD) protein and FIH-1 (factor inhibiting HIF-1), because both enzymes require oxygen as co-substrate. Inhibition of the PHD results in HIF-1 $\alpha$ stabilization to bind CREB-binding protein (CBP)/p300 and run a perfect transcription activity. Accumulation of HIF-1 $\alpha$ in the cytoplasm under hypoxic condition occurs rapidly. After phosphorylation, HIF-1 $\alpha$ is translocated into the cell nucleus for dimerization with its partner HIF- $1 \beta$ forming the transcription factor HIF-1. Through the activation of HIF-1, expression of a number of genes that 


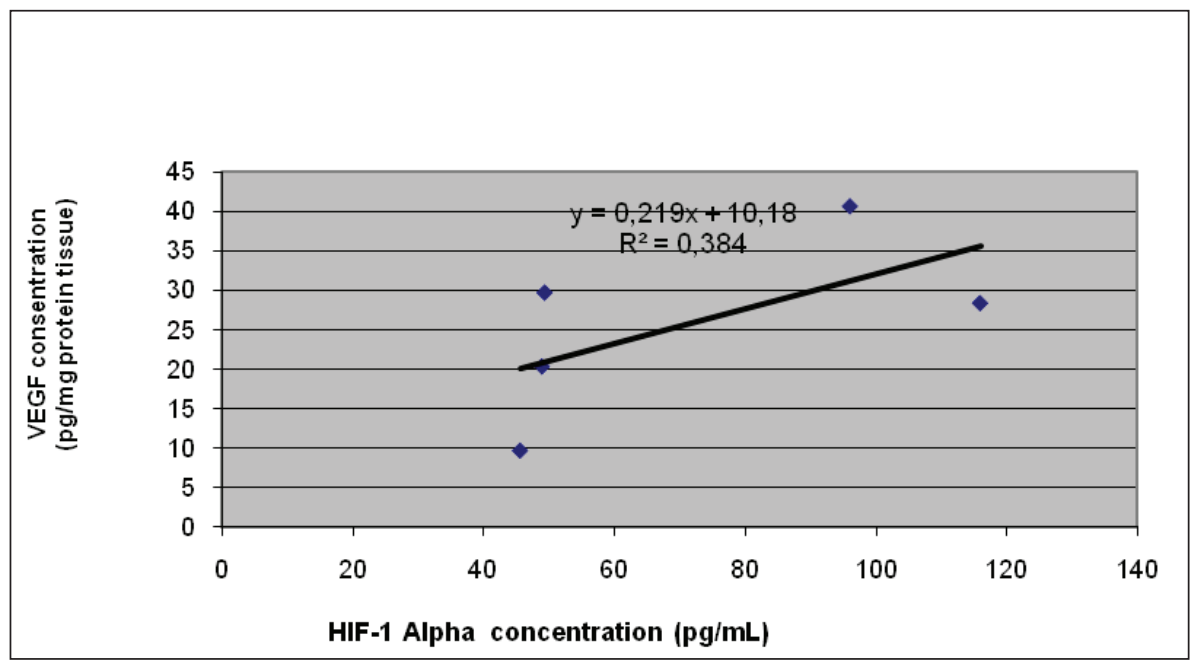

Figure 3. Correlation between tissue concentrations of HIF-1 $\alpha$ and VEGF in aerobic groups

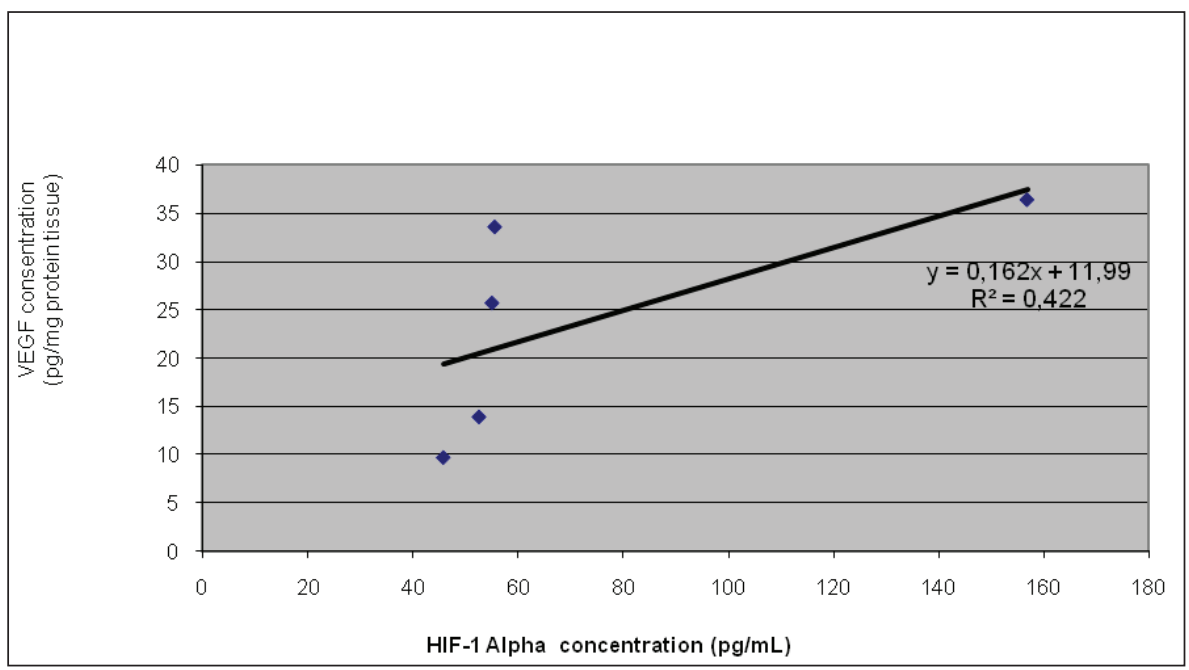

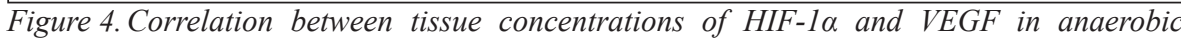
groups

encode enzymes, growth factors and transporters reduce the dependence of the cells on oxygen and simultaneously increase the supply of oxygen to the system. ${ }^{5}$

The concentration of HIF-1 $\alpha$ increases because of the high oxygen demand during exercise to meet energy needs. Hypoxia is known to occur in skeletal muscle tissue under exercise, but the heart muscle plays a special role. During life, the heart has always to contract. To maintain its function in the face of various loads, continuous availablity of oxygen and other substrates is necessary. Increased oxygen demand during exercise will also result in increased oxygen delivery to the heart. ${ }^{2}$

Our study shows that concentrations of HIF-1 $\alpha$ on the first day are higher in the anaerobic than in the aerobic group, but differences are statistically not significant. In both groups HIF- $1 \alpha$ concentrations are significantly increased $v s$. controls. Anaerobic condition triggers the accumulation of HIF- $1 \alpha$ and thus, the activation of HIF-1.

Moreover, HIF-1 plays a role in the transition from aerobic to anaerobic metabolism to produce energy through anaerobic glycolysis..$^{5}$ This transition is an adaptive response for energy to remain available even if oxygen is not sufficiently supplied. ${ }^{2}$ Transcription factor HIF- $1 \alpha$ is very important in maintaining ATP levels in the cells. ${ }^{6}$ It induces glucose transporters and glycolytic enzymes such as aldolase A, pyruvate kinase $\mathrm{M}$ helping to produce energy in hypoxic state. HIF-1 increases the expression of these enzymes and activates pyruvate dehydrogenase kinase I so that the citric acid cycle becomes deactivated. ${ }^{10}$

Our results are comparable to Jusman et al. ${ }^{11}$ who induced systemic hypoxia in mice using a mixture 
of $92 \%$ nitrogen and $8 \%$ oxygen. A sharp increase in HIF- $1 \alpha$ mRNA of liver tissue on the first day was followed by a gradual decline until the $14^{\text {th }}$ day. ${ }^{11}$ According to Shao et al. ${ }^{12} \mathrm{HIF}-1 \alpha$ mRNA expression increases in acute hypoxia, whereas in hypoxia over time it declines again.

Moreover, studies on heart and brain with induced systemic hypoxia in rats indicate that the occurrence of elevated levels of HIF- $1 \alpha$ mRNA is relative. ${ }^{13}$ The expression reached a peak on day 7 of hypoxia in the heart and in the brain on day 14 and after the respective peaks, HIF-1 $\alpha$ mRNA expression decreased again. ${ }^{13}$ Research on rat kidneys using a hypoxic induction model, also resulted in increased HIF- $1 \alpha$ mRNA with peaks on days 1 and 7 and a subsequent decrease. ${ }^{14}$

Apart from the differences in various organs, the above findings indicate that the responsive pathway to early hypoxic adaptation is obtained by increasing the expression of HIF-1 $\alpha$ gene. If the hypoxic condition continues, increased HIF-1 $\alpha$ gene expression is gradually replaced with HIF-1 $\alpha$ protein stabilization, i.e. by inhibition of protein degradation. ${ }^{14}$

Research conducted by Ferdinal et al. ${ }^{15}$ with induced systemic hypoxia in mice showed that the concentration of HIF- $1 \alpha$ in cardiac muscle increased from day 7 and peaked on day 21 . HIF-1 $\alpha$ mRNA expression increased gradually. Day 21 appeared to be the beginning of more severe cardiac dysfunction in extended hypoxia. ${ }^{15}$

In our model of aerobic and anaerobic exercise HIF-1 $\alpha$ protein increases immediately in cardiac muscle, on the first day. The reason for this rapid increase is the high oxygen demand to continue exercise. This situation causes the drop of $\mathrm{P}_{\mathrm{O} 2}$ and increases HIF-1 $\alpha$, which is sensitive to decreased levels of $\mathrm{O}_{2}$. In addition, during aerobic and anaerobic exercise the heart muscle must work harder pumping blood to meet the needs of the body. Mechanical stress can induce the accumulation of HIF-1 $\alpha$. Induction of HIF- $1 \alpha$ can result from stretching the heart wall. ${ }^{16}$

In line with the duration of exercise, HIF-1 $\alpha$ concentrations decreased to levels close to control values. In other words, a certain level of HIF-1 $\alpha$ is maintained in cardiac muscle not only under hypoxic but also in the normoxic condition of the control group (Figure 1). In heart muscle, HIF-1 $\alpha$ stability is required to sustain cardiac function because every contraction compresses coronary blood vessels in the depth of the myocardium causing a transient short hypoxia not only in hypoxic but also in normoxic state. Without maintenance of HIF-1 $\alpha$, ATP synthesis and thus, ATP tissue levels probably decrease in myocardium resulting in cardiac contractile dysfunction. According to Cramer et $\mathrm{al}^{17}$ certain tissues are under the influence of HIF- $1 \alpha$ not only in hypoxia but also in normoxia if it is necessary to maintain metabolic functions.

Stroka et $\mathrm{al}^{18}$ found HIF- $1 \alpha$ in the nucleus of endothelial cells and arterial myocytes in the heart muscle under normoxic condition. In myocardium, the stability of HIF- $1 \alpha$ is required for the activation of transcription of several genes that are sensitive to normoxic oxygen conditions and hypoxia. In normoxia, there are several mechanisms to increase the stability and activity of HIF$1 \alpha$. Activation of HIF-1 $\alpha$ may occur through $\mathrm{p} 44 / 42$ MAPK (mitogen activated protein kinases) by various cytokines and growth factors through tyrosine kinase receptors, which in turn can activate phosphatidyl inositol 3-kinase to increase the transcriptional activity of HIF. In addition, nitric oxide can accumulate HIF-1 $\alpha$ in normoxia via inhibition of its hydroxylation as the startpoint of degradation. ${ }^{16}$

Tissue concentration of VEGF in myocardium significantly increased in all anaerobic groups compared with the control group. In the aerobic group, the difference vs. control was significant only on day $10(\mathrm{p}<0.05)$. VEGF concentration differed significantly $(p<0.05)$ between aerobic and anaerobic groups on days 1,3 and 10 (Figure 2).

VEGF plays an important role in stimulating angiogenesis through proliferation and migration of endothelial cells and tubulus formation. ${ }^{19}$ Kinetics of VEGF mRNA expression in muscle cells under acute exercise were reported by Breen et al. ${ }^{20}$ VEGF mRNA expression increased immediately after exercise commenced, decreased within 2 hours and returned to basal levels after 8 hours of continual activity. ${ }^{20}$ Increased VEGF mRNA in muscle cells results in increased synthesis of VEGF protein, which is released into the extracellular matrix and into blood circulation. In cultured skeletal muscle cells, electrical stimulation increased the secretion of VEGF and mechanical stimulation induced VEGF secretion from myocytes of mice into the extracellular matrix. ${ }^{21}$ In exercise, muscle contraction causes local mechanical stress, which stimulates the expenditure of VEGF protein from myocytes into the extracellular matrix. ${ }^{22}$

Furthermore, exercise decreases $\mathrm{P}_{\mathrm{O} 2}$ which triggers VEGF mRNA expression. The intracellular oxygen concentration plays a role in the response of skeletal muscle for angiogenesis. ${ }^{20}$ Hypoxia increases VEGF expression through HIF-1 regulation, i.e., if HIF-1 $\alpha$ and HIF- $1 \beta$ are increased. ${ }^{6}$ In skeletal muscle, increased VEGF mRNA is associated with increased HIF-1 $\alpha$ mRNA indicating the role of HIF- $1 \alpha$ in VEGF gene 
expression. ${ }^{6} \mathrm{HIF}-1 \alpha$ affects the transcription of VEGF and hypoxia results in an increased post-transcriptional stability of VEGF mRNA. In skeletal muscle of experimental mice, VEGF mRNA increased four-fold after a single bout treadmill run and an even higher increase occurred during exercise performed in a hypoxic state. ${ }^{20}$

In muscle capillary, Lyod et $\mathrm{a}^{23}$ reported an increase in VEGF mRNA during the early period of exercise. However, no change in capillary activity was observed until day 12 of exercise. In chronic stimulation of muscle activity, angiogenesis occured earlier, at day 5 of exercise..$^{23}$

In our study, anaerobic exercise triggers increased VEGF concentraion more rapidly than in the aerobic groups. Our interpretaion is that in anaerobic condition neovascularization is needed faster than in aerobic exercise.

Under clinical ischemic conditions, adaptation mechanisms occur in the myocardium including neovascularization into ischemic areas in order to limit myocardial damage and to improve its function. ${ }^{24}$ Results from heart muscle biopsies in patients with ischemia and infarction showed increased levels of HIF$1 \alpha$ and VEGF mRNA. Expression of VEGF remained longer than that of HIF- $1 \alpha .{ }^{24}$ Probably, HIF-1 $\alpha$ response to ischemia occurs earlier and is temporary, whereas expression of VEGF responds to extended conditions in order to repair heart muscle tissue and to limit cellular damage caused by longer-lasting hypoxia.

As stated above, most studies on exercise have been carried out in skeletal muscle. The myocardium was widely investigated under pathological and pharmacotherapeutic conditions, e.g., ischemiareperfusion or intentionally induced hypoxia. For the first time, we showed the correlation of HIF-1 $\alpha$ and VEGF in the myocardium with an experimental animal model under normal conditions in anaerobic and aerobic exercise, i.e., without intentionally induced hypoxia. We described the differences between the patterns of the two proteins during the course of exercise and the differences of their correlation in anaerobic and aerobic conditions. We consider this knowledge very important for training programs of athlets - especially to prevent often occuring sudden deaths from heart failure, for the counseling to our non-athletic population concerning their physical activities, as well as for the rehabilitation of patients.

In conclusion, aerobic and anaerobic exercise leads to increased concentrations of HIF-1 $\alpha$ and VEGF in myocardium. The concentration patterns of the two proteins differ between anaerobic and aerobic conditions.
The correlation between the concentrations of VEGF and HIF-1 $\alpha$ is stronger in anaerobic than in aerobic exercise.

\section{REFERENCES}

1. Kusmana D. Olahraga untuk orang sehat dan penderita penyakit jantung. 2nd ed. Jakarta: FKUI; 2006.

2. Foss ML, Keteyian SJ. Physiological basis for exercise and sport. New York: McGraw-Hill; 2006. p.59-64.

3. Gabhann FM, Ji JW, Popel AS. VEGF gradients, receptor activation and sprout guidance in resting and exercise skeletal muscle. J Appl Physiol. 2007;102:722-34.

4. Booth FW, Chakravarthy MV, Spangenburg EE. Exercise and gene expression: physiological regulation of the human genome through exercise. J Physiol. 2002;543:399-431.

5. Semenza GL. Hydroxylation of Hif-1 $\alpha$ : Oxygen sensing at the molecular level. Physiology. 2004;19:176-82.

6. Gustafsson T, Puntschart A, Kaijser L, Jansson E, Sundberg CJ. Exercise-induced expression of angiogenesis-related transcription and growth factors in human sceletal muscle. Am J Physiol. 1999;45:679-85.

7. Zheng W, Seftor EA, Meininger CJ, Hendrix MJC, Tomanex RJ. Mechanisms of coronary angiogenesis in response to stretch: role of VEGF and TGF- $\beta$. Am J Physiol Heart Circ Physiol. 2001;280:909-17.

8. Fahrenia RR. Ekspresi Gen mioglobin dan serum kreatinfosfokinase pada aktivitas fisik aerobik dan anaerobik sebagai indikator hipoksia dan kerusakan jantung otot tikus wistar [dissertation]. Bandung (Indonesia) Universitas Padjadjaran; 2009.

9. Soya H, Mukai A, Deocaris, Ohiwa N, Nishijima, Fujikawa $\mathrm{T}$, et al. Threshold-like pattern of neuronal activation on the hypothalamus during treadmill running: establishment of minimum running stress (MRS) rat model. Neuroscience Res. 2007;58:341-8.

10. Vaupel P. The Role of Hypoxia-Induced Factors in Tumor Progression. Oncologist. 2004;9:10-17.

11. Jusman SWA, Halim A, Wanadi SI, Sadikin M. Expression of hypoxia-inducible factor-1 $\alpha$ (HIF-1 $\alpha$ ) related to oxidative stress in liver of rat-induced by systemic chronic normobaric hypoxia. Acta Med Indones-Indones J Intern Med. 2010;42(1):17-23.

12. Shao G, Gao CY, Lu GW. Alterations of hypoxiainducible factor-1 alpha in the hippocampus of mice acutely and repeatedly exposed to hypoxia. Neurosignal. 2005;14(5):255-61.

13. Wanadi SI, Dewi S, Paramita R. Ekspresi relatif mRNA HIF-1 $\alpha$ pada jantung, otak dan darah tikus selama induksi hipoksia sistemik. Makara Sains. 2009;13(2):185-8.

14. Prijanti AR. Peran HIF-1 $\alpha$ dalam pengaturan ekspresi renin pada hipoksia [dissertation]. Jakarta: Universitas Indonesia; 2010.

15. Ferdinal F, Suyatna FD, Wanadi SI, Sadikin M. Expression of B-type natriuretic peptide-45 (BNP-45) gene in the ventricular myocardial induced by systemic chronic 
hypoxia. Acta Med Indones-Indones J Intern Med. 2009;4(13):136-43.

16. Metzen E, Ratcliffe PJ. HIF hydroxylation and cellular oxygen sensing. J Biol Chem. 2004;385:223-30.

17. Cramer T, Yamanishi Y, Clausen BE, Forster I, Pawlinski $\mathrm{R}$, Mackman N, et al. HIF-1 alpha is essential for myeloid cell-mediated inflammation. Cell. 2003;112:645-57.

18. Stroka D, Candinas D. Hypoxia-inducible factor-1 signaling system. In : Dufour JF, Clavien PA, Trautwein C, Graf R, editors. Signaling pathways in liver disease. Part II. Berlin, Heidelberg: Springer. 2005;26:311-23.

19. Gustaffson T, Knutsson A, Puntschart A, Kaijser L, Nordqvist AC, Sundberg CJ, et al. Increased expression of vascular endothelial growth factor in human skeletal muscle in response to short-term one-legged exercise training. Pflugers Arch. 2002;444:752-9.

20. Breen EC, Johnson EC, Wagner H, Tseng HM, Sung LA, Wagner PD. Angiogenic growth factor mRNA responses in muscle to a single bout of exercise. J Appl Physiol. 1996;81:355-61.

21. Lee SH, Wolf PL, Escudero R, Deutsch R, Jumieson SW, Thistlethwaite PA. Early expression of angiogenesis factors in acute myocardial ischemia and infarction. N Engl J Med. 2000;342:626-33.

22. Hiscock N, Fischer CP, Pilegaard H, Pedersen BK. Vascular endothelial growth factor mRNA expression and arteriovenous balance in response to prolonged, submaximal exercise in humans. Am J Physiol Heart Circ Physiol. 2003;285:H1759-63.

23. Lloyd PG, Prior MB, Yang HT. Angiogenic growth factor expression in rat skeletal muscle in response to exercise training. Am J Physiol. 2002;281:H2528-38.

24. Sabia PJ, Powers ER, Ragosta M, Sarembock IJ, Burwell LR, Kaul S. An association between collateral blood flow and myocardial viability in patients with recent myocardial infarction. N Engl J Med 1992;327:1825-31. 